\title{
Identification of Trihalomethanes (THMs) Levels in Water Supply: A Case Study in Perlis, Malaysia
}

\author{
Mohd Faizal Ab Jalil ${ }^{1 *}$, Nasrul Hamidin ${ }^{2}$, Ahmad Anas Nagoor Gunny ${ }^{3}$, and Ain Nihla \\ Kamarudzaman $^{2}$ \\ ${ }^{1}$ Perlis State Department of Environment, ${ }^{\text {nd }}$ Floor, KWSP Building, Jalan Bukit Lagi, 01000 \\ Kangar, Perlis, Malaysia. \\ ${ }^{2}$ School of Environmental Engineering, Universiti Malaysia Perlis, Kompleks Pusat Pengajian Jejawi \\ 3, 02600 Arau, Perlis, Malaysia. \\ ${ }^{3}$ Department of Chemical Engineering Technology, Faculty of Engineering Technology, Universiti \\ Malaysia Perlis, Kampus UniCITI Alam, Sungai Chuchuh, 02100 Padang Besar, Perlis, Malaysia.
}

\begin{abstract}
In Malaysia, chlorination is used for drinking water disinfection at water treatment plants due to its cost-effectiveness and efficiency. However, the use of chlorine poses potential health risks due to the formation of disinfection by-products such as trihalomethanes (THMs). THMs are formed due to the reaction between chlorine and some natural organic matter. The objective of the study is to analyze the level of THMs in the water supply in Perlis, Malaysia. The water samples were collected from end-user tap water near the water treatment plant (WTP) located in Perlis, including Timah Tasoh WTP, Kampung Sungai Baru WTP, Arau Phase I, II, III, and IV WTPs. The THMs were analyzed using a Gas Chromatography-Mass Spectrometry (GC/MS). The results showed that the water supply from Timah Tasoh WTP generates the most THMs, whereas Kuala Sungai Baru shows the fewest amounts of total THMs. In conclusion, the presence of THMs in tap water has caused great concern since these components can cause cancer in humans. Therefore, the identification of THM formation is crucial in order to make sure that the tap water quality remains at acceptable safety levels.
\end{abstract}

\section{Introduction}

Chlorine is usually used in water treatment as a disinfectant agent and is very effective in reducing and eliminating waterborne diseases such as typhoid, cholera, hepatitis, dysentery, and gastrointestinal illness. $[1,2,3,5]$. Chlorine reacts with organic matter in water to form Disinfected By-Products (DBPs) such as trihalomethanes (THMs), haloacetic acids (HAAs), and other compounds that are hazardous to human health $[5,6,8,13,14,15]$. DBPs have established a large family of compounds and produce various stages of toxicological effects. THMs and HAAs are the major groups of DBP in drinking water.

\footnotetext{
* Corresponding author: faj@doe.gov.my
} 
Their establishment should be known and their level of compliance enforced in many countries (especially THMs and HAAs) $[4,9,11]$.

The formation, speciation, and concentration of CBPs in drinking water vary according to several factors related to water source characteristics, as well as operational parameters during treatment and drinking water distribution system characteristics $[6,10]$. Hence, the aim of this paper is to identify the presence of DBP in the water distribution system in Malaysia, particularly in Perlis state. For this reason, the study is carried out on the following procedures. Firstly, water samples are collected from end-user tap water near several water treatment plants (WTP) located in Perlis such as Timah Tasoh WTP, Kampung Sungai Baru WTP, and Arau Phase I, II, III, and IV WTPs. Second, the samples are analyzed to detect the presence of several types and concentration of THMs using Gas Chromatography-Mass Spectrometry.

\section{Methodology}

Water samples were collected from four different water treatment centers in Perlis which are Timah Tasoh, Kampung Sungai Baru, Arau Phase I, II, and III, and Arau Phase IV water treatment plants as shown in Fig. 1, Fig. 2 and Fig. 3.

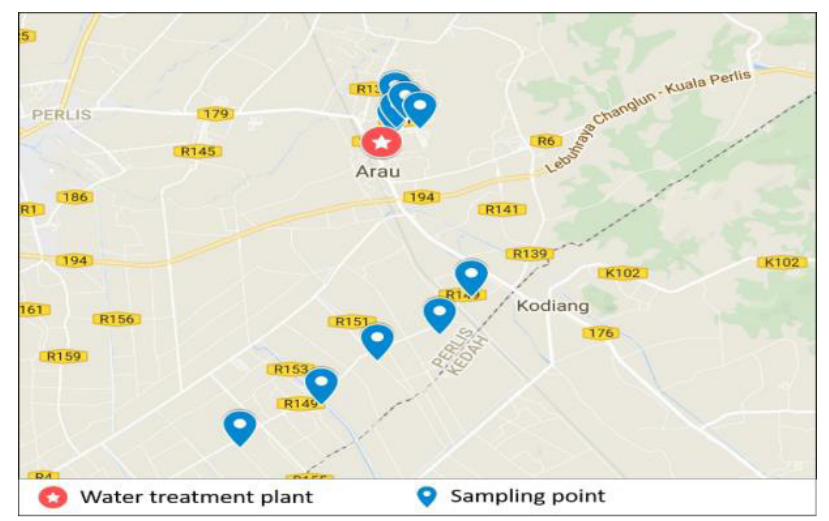

Fig. 1. Location of Arau Phase I, II, III \& IV WTC and sampling point for the following location. Taken from Map Data (C2017 Google.

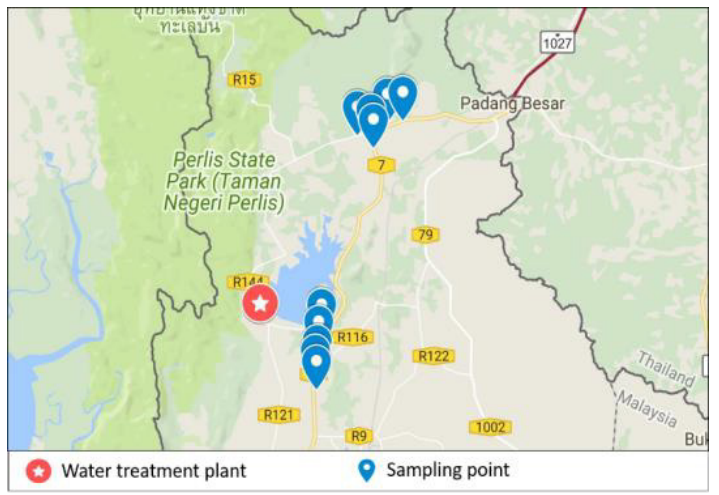

Fig. 2. Location of Timah Tasoh WTC and sampling point for the following location. Taken from Map Data (C2017 Google. 


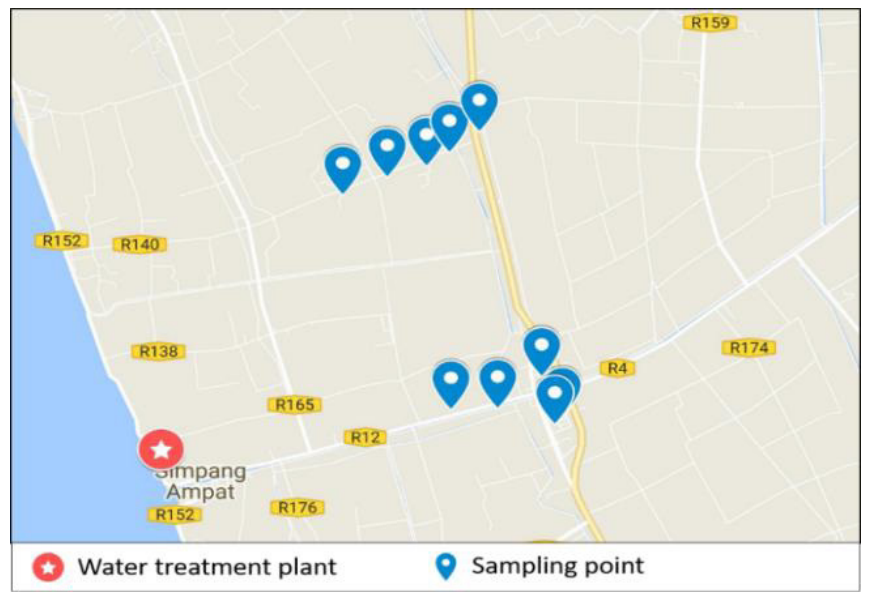

Fig. 3. Location of Kuala Sungai Baru WTC and sampling point for the following location. Taken from Map Data (C2017 Google.

However, since the water supplies from Arau Phase I, II, and III are combined with the Arau Phase IV water treatment plant inside a storage tank before being sent to the users, these treatment plants are considered to be one plant instead of two. After the sampling process was done, it was analyzed in the lab within 14 days of the extraction time, as suggested in USEPA 551.1. Standard quality controls also are carried out according to USEPA to check for instrument and laboratory capability. The water samples were analyzed by using Gas Chromatography-Mass Spectrometry with the following condition: the types of column are HP-5, the length of the column is $30 \mathrm{~m}$, and the Injector and Detector Temperature are $200^{\circ} \mathrm{C}$ and $260^{\circ} \mathrm{C}$ respectively.

\section{Results and discussions}

\subsection{THMs exposure levels}

The total number of THMs was found to be different in every location. The location is indicated by the number of samples, as shown in following; a) Sample 1 to 30: WTP Timah Tasoh, b) Sample 31 to 60: WTP Kuala Sungai Baru and c) Sample 61 to 90: WTP Arau Phase 1, 2, $3 \& 4$. Chloroform was found to be higher than other elements, especially in the Timah Tasoh area where some of it has violated the limit provided by WHO and USEPA as shown in Fig. 4.

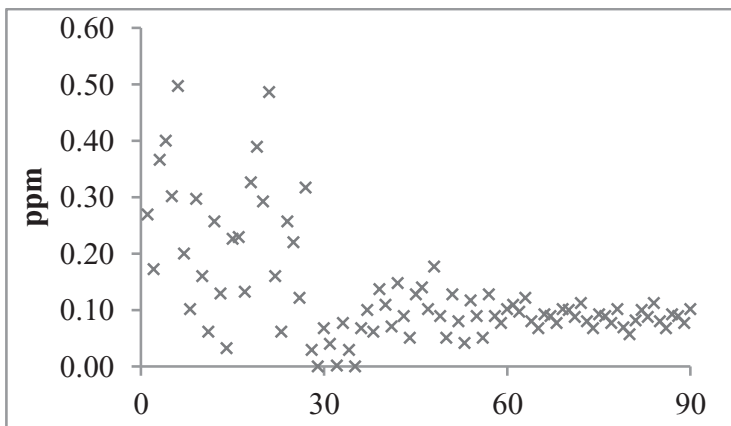

Fig. 4. Chloroform of end-user water samples. 


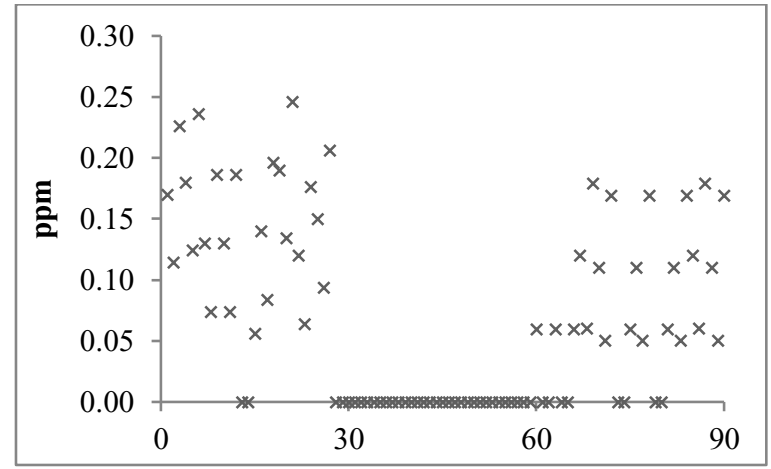

Fig. 5. Bromodichloromethane at end-user water samples.

Even though the $\mathrm{pH}$ around the area is slightly higher as compared to other locations, the chloroform formation seems to be contrasted to the report by Singer \& Shi (2008) [12] where they claim the formation of chloroform is supposed to be lower in higher $\mathrm{pH}$. However, this does not count other factors such as the present of ammonia in the raw water and the time contact between the chlorine and water. It is known that the pipeline between WTP to the household is the longest at Timah Tasoh, and due to the fact that it is a large area and with the current earth surface condition, it requires a long pipeline. The longer the pipeline system is, the higher the amount of organic matter buildup, especially when the storage and delivery tank are involved. So, all these factors will affect the formation of chlorine despite the fact that it has a higher $\mathrm{pH}$.

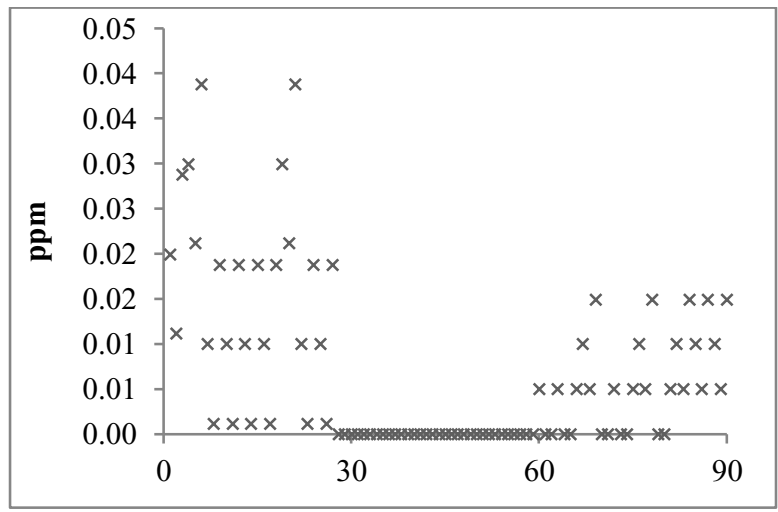

Fig. 6. Dibromochloromethane at end-user water samples.

The area that receives a water supply from Kuala Sungai Baru shows the best results in this study. This is because its location is close to the residential area, thus required a shorter piping system. Since there is no storage tank is being used in this area, contributing factors such as organic buildup were automatically eliminated. That explains the unavailability of certain THMs in the water samples. 
Table 1. WHO guidelines [15].

\begin{tabular}{|l|c|}
\hline Parameter & $\begin{array}{c}\text { WHO Guidelines value } \\
(\mathbf{m g} / \mathbf{L})\end{array}$ \\
\hline Chloroform & 0.20 \\
\hline Dichlorobromomethane & 0.06 \\
\hline Dibromochloromethane & 0.10 \\
\hline Bromoform & 0.10 \\
\hline Total THM & $<0.001$ \\
\hline
\end{tabular}

Table 2. Variation of THMs level in the tap water received by end-user in 3 WTP areas.

\begin{tabular}{|c|c|c|c|c|c|}
\hline Location & TCM & DCBM & DBCM & TBM & Unit \\
\hline \multicolumn{5}{|c|}{ Timah Tasoh } & \multirow{4}{*}{$\mathrm{mg} / \mathrm{L}$} \\
\hline $\operatorname{Max}$ & 0.50 & 0.25 & 0.04 & $<0.03$ & \\
\hline Min & 0.00 & $<0.07$ & 0.00 & $<0.03$ & \\
\hline Mean & 0.22 & 0.12 & 0.01 & $<0.03$ & \\
\hline \multicolumn{5}{|c|}{$\begin{array}{l}\text { Kuala Sungai } \\
\text { Baru }\end{array}$} & \multirow{4}{*}{$\mathrm{mg} / \mathrm{L}$} \\
\hline Max & 0.18 & $<0.07$ & 0.01 & $<0.03$ & \\
\hline Min & 0.00 & $<0.07$ & 0.00 & $<0.03$ & \\
\hline Mean & 0.09 & $<0.07$ & 0.00 & $<0.03$ & \\
\hline \multicolumn{5}{|c|}{$\begin{array}{l}\text { Arau Phase I, } \\
\text { II, III \& IV }\end{array}$} & \multirow{4}{*}{$\mathrm{mg} / \mathrm{L}$} \\
\hline Max & 0.12 & 0.18 & 0.02 & $<0.03$ & \\
\hline Min & 0.06 & $<0.07$ & 0.00 & $<0.03$ & \\
\hline Mean & 0.09 & 0.08 & 0.01 & $<0.03$ & \\
\hline
\end{tabular}

\section{Conclusions}

This paper shows that THM formation is the highest in the tap water supplied by WTP Timah Tasoh, and the lowest amount of THMs is in tap water supplied by WTP Kuala Sungai Baru. Some of it even violated the guidelines provided by WHO [15]. The range of THM concentrations in all the areas is between $0.00 \mathrm{mg} / \mathrm{L}$ to $0.50 \mathrm{mg} / \mathrm{L}$ for all compounds. Chloroform $\left(\mathrm{CHCl}_{3}\right)$ dominated the results, followed by bromodichloromethane $\left(\mathrm{CHCl}_{2} \mathrm{Br}\right)$. The other two almost give no results in this study, especially bromoform $\left(\mathrm{CHBr}_{3}\right)$. The formation of THMs in the water received by the end-user has caused great concern since these substances can cause cancer in humans. This paper describes a few parameters that need to be taken consideration when conducting a standard testing. This is to reduce the possible error that can distort the results of the analysis.

The authors would like to thank School of Environmental Engineering, UniMAP and Universiti Teknologi MARA (Arau) for providing the instruments used in the analysis throughout the study.

\section{Reference}

1. R.L., Calderon, Food Chem. Toxicol. 38 (12) (2000)

2. W., Gan, W., Guo, J., Mo, Y., He, Y., Liu, W., Liu, Y., Liang, X., Yang, Sci. of the Total Environ, 447, 108 - 115 (2013)

3. S.K., Golfinopoulos, A.D., Nikolaou, Desalination 176, 13 - 24 (2005)

4. S., Guilherme, M.J., Rodriguez M.J., Chemosphere 117, 425-432 (2014)

5. N., Hamidin, Q.J., Yu, D.W., Connell, Water Res. 42, 3263 - 3274 (2008) 
6. C. Legay, M.J., Rodriguez, R., Sadiq, J.B., Serodes, P., Levallois, F., Proulx, J. of Environ. Man. 92, 892 - 901 (2011).

7. M.Y. Perlis, Google Maps. Google. Retrieved from https://www.google.com.my/maps/place/Perlis/@6.2895831,100.3726868,10z/data=! 4m5!3m4!1s0x304c7916f2d4bdf9:0x675ec9fc75fcfb6f!8m2!3d6.4449129!4d100.204 7691 ?hl=en

8. S.D., Richardson, Trends Anal. Chem. 22 (10), 666 - 884 (2003)

9. S.D., Richardson, Encyclopedia of Environmental Health (Elsevier, Burlington, 2011)

10. M.J., Rodriguez, J.B., Serodes, P., Levallois, Water Res. 38 (20), 4367 - 4382 (2004)

11. P.C., Singer, Water Sci. Technol. Water Supply 2 (5-6), 487-492 (2002)

12. P.C., Singer, J., Shi, Control of Haloacetic Acid Formation in North Carolina Drinking Water (2008)

13. V., Uyak, K., Ozdemir, I., Toroz, Sci. of the Total Environ. 390, $417-424$ (2008)

14. J., Wei, B., Ye, W., Wang, L., Yang, J., Tao, Z., Hang, Sci. of the Total Environ. 408, $4600-4606$ (2010)

15. WHO, Guidelines for drinking-water quality $3^{\text {rd }}$ Ed. (World Health Organization, Geneva, 2004) 